inflammatory role in the pathology of RA and PsA. As this effect can be reversed by Ang- 2 neutralisation, interfering with Tie 2 activity may be a promising therapeutic target in arthritic diseases.

Disclosure of Interest: S. García Pérez: None declared, P. A. Kabala: None declared, B. Malvar Fernández: None declared, M. W. Tang: None declared, S. A. Hartgring: None declared, C. Conde: None declared, M. Sleeman Employee of: Formerly an employee at Medlmmune for the duration of this collaboration, D. L. Baeten: None declared, P. P. Tak: None declared, J. Connor Employee of: Medlmmune LCC, K. A. Reedquist: None declared, T. R. Radstake: None declared DOI: 10.1136/annrheumdis-2018-eular.3604

\section{THU0092 INTRA-CYTOPLASMIC CYTOKINES IN CD20 POSITIVE LYMPHOCYTE SUBPOPULATIONS IN RHEUMATOID ARTHRITIS (RA) PATIENTS}

S. Aamar ${ }^{1}$, A. Kerpel ${ }^{2}$, R. Rabinowitz ${ }^{2}$, P. Levy ${ }^{2}$, O. Zelig ${ }^{1}$, N. Schlesinger ${ }^{3}$, M. Schlesinger ${ }^{2} .{ }^{1}$ Hadassah hospital; ${ }^{2}$ Hebrew University Medical School, Jerusalem, Israel; ${ }^{3}$ Rutgers Robert Wood Johnson Medical School, New Brunswick, USA

Background: The administration of biological drugs inactivating various elements of the immune system such as cytokines and immune cells, induces a significant ameliorating effect on rheumatoid arthritis (RA) patients. The mechanisms involved in the pathogenesis of RA are unclear, and the precise role of different cellular elements of the immune system in its pathogenesis remain to be elucidated.

Objectives: In the present study we concentrated on one cellular target for a biologic treatment in RA (Rituximab), the CD20 positive lymphocytes. Various types of lymphocytes are positive to CD20. Based on its expression, these lymphocytes include dim and bright CD20 +types. These cells' capacity to secrete various cytokines was determined among lymphocytes of healthy controls $(\mathrm{HC})$ and RA patients.

Methods: Peripheral blood lymphocytes (PBL) of RA patients $(n=20)$ and HC $(n=15)$ were isolated using Ficoll Hypaque gradient columns. To $5 \times 10^{5}$ cells in $0.5 \mathrm{ml}$ RPMl-1640 medium, $1.25 \mathrm{ng}$ PMA, $0.5 \mu \mathrm{g}$ lonomycin and $5 \mu \mathrm{g}$ Brefeldin were added for 5 hours of activation after which cells were incubated for 30 min at $4^{\circ} \mathrm{C}$ with Phycoerythrin-(PE) conjugated anti-CD20 monoclonal antibody (mab). Thereafter, suspensions were incubated in fixation buffer for $45 \mathrm{~min}$, washed and re-suspended in $100 \mu \mathrm{l}$ of permeabilization buffer and $20 \mu \mathrm{l}$ of fluorescent (FITC) conjugated anti-cytokine mabs, and were incubated at $4^{\circ} \mathrm{C}$ for $30 \mathrm{~min}$. A t-test for independent samples, was performed.

Results: Intra-cytoplasmic detection of various key-role cytokines, such interleukins 4 (IL-4), 17 (IL-17), 10 (IL-10) and interferon gamma (INF- $\gamma$ ) was determined. The percentage of IL-4 positive lymphocytes among CD20 +cells in $\mathrm{HC}$ was higher in CD20 +dim cells (4.5\%) than in CD20 +bright cells $(1.2 \%)$ ( $p$ value 0.0001 ). Among lymphocytes of RA patients the proportion of IL-4 positive cells was much higher than in $\mathrm{HC}(\mathrm{p}<0.0002)$ and was comparable between dim $(54.5 \%)$ and bright $(48.6 \%)$ CD20 +lymphocytes. The proportion of IL-10 positive cells among both dim and bright CD20 +lymphocyte subpopulations was significantly lower in RA patients than in $\mathrm{HC}(\mathrm{p}<0.0002)$. While in $\mathrm{HC}, 56 \%$ of CD20 +dim and $61 \%$ of CD20 +bright lymphocytes, showed IL-10 positivity, among RA lymphocytes it constituted only $17.8 \%$ and $9.3 \%$ of the CD20 +dim and bright lymphocytes, respectively.

Staining with anti-IL-17 mab yielded in low proportions of IL-17 positive cells in all CD20 +populations tested, in both $\mathrm{HC}$ and $\mathrm{RA}$. Among dim CD20 +lymphocytes, IL-17 positive cells constituted $1.4 \%(\mathrm{HC})$ and $3.6 \%$ (RA). IL-17 staining appeared on only $0.74 \%$ of CD20 +bright lymphocytes in $\mathrm{HC}$ and similarly in RA $(0.54 \%)$. While the proportion of INF- $\gamma$ positive lymphocytes was similar in $\mathrm{HC}$ and $\mathrm{RA}$, it was significantly higher among dim $(11.8 \%$ $\mathrm{HC}, 9.5 \% \mathrm{RA})$ than in bright CD20+ $(1 \% \mathrm{HC}, 1.4 \% \mathrm{RA})$ indicating a different cell pattern $(p=0.0001)$

Conclusions: The present study demonstrates that CD20 +lymphocytes, targeted in RA treatment, expressing different levels of CD20, in RA differ from $\mathrm{HC}$ in their capacity to produce various cytokines. Although there was no difference in $\mathrm{IL}-17$ and INF- $\gamma$ they may modulate the immune response in RA due to higher levels of IL- 4 and reduced IL-10 levels produced by both CD20 +cell populations; dim and bright lymphocytes.

Disclosure of Interest: None declared

DOI: 10.1136/annrheumdis-2018-eular.2235

\section{THU0093 \\ NADPH OXIDASES ASSOCIATED PRODUCTION OF REACTIVE OXYGEN SPECIES IN RHEUMATOID ARTHRITIS}

S.-J. Yoo, S.W. Kang, J. Kim, I.S. Yoo, C.K. Park. Internal Medicine, Chungnam National University School of Medicine, Daejeon, Korea, Republic of Ireland

Background: Reactive oxygen species (ROS) is produced during metabolism of Oxygen. ROS is important in cell signalling and homeostasis. Production of ROS can be elevated in stressful condition. Oxidative stress has been known to be related with the disease like infection and malignancy. NADPH oxidases (Nox) are membrane proteins which produce ROS.

Objectives: In this study we aimed to investigate the role of Nox in rheumatoid arthritis (RA) associated with production of ROS.

Methods: Nox and Granulocyte macrophage colony-stimulating facto (GMCSF) messenger ribonucleic acid (mRNA) were analysed in fibroblast like synoviocyte (FLS) of patients with RA and osteoarthritis (OA) by reverse transcription polymerase chain reaction. Amount of ROS which is produced in FLS of patients with RA and $O A$ is determined using the cell permeant fluoroprobe 5-(and-6)-chloromethyl-2',7'-dichlorodihydrofluorescein diacetate acetyl ester (CM-H2DCFDA) by flowcytometry. Same experiments were performed after treatment with cytokine, interleukin (IL) -17 and tumour necrosis factor- $\alpha$ (TNF- $\alpha$ ).

Results: Among Nox subunits (Nox1, Nox2, Nox4, Nox5, DUOX1, DUOX2, NOXA1, NOXO1), NOXA1 and NOXO1 mRNA were expressed higher in RA FLS than in OA FLS. After treatment with IL-17 and TNF- $\alpha$ for 24 hours GMCSF, Nox1 and NOXO1 mRNA in RA FLS were elevated. Amount of ROS production was also elevated after treatment with IL-17 and TNF- $\alpha$. When RA FLS were treated with bromopyruvic acid ( $\mathrm{BrPa})$, glucolysis inhibitor by inhibition of hexokinase II GMCSF mRNA and ROS were decreased and Nox1 and Nox4 mRNA showed no diffrence.
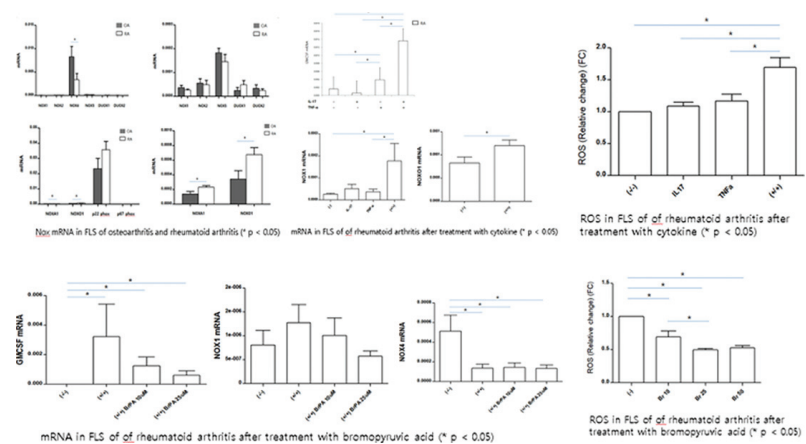

Conclusions: Several factors may be involved between ROS and Nox in RA FLS. Both ROS and Nox were elevated in inflammatory condition in RA FLS From this result we expect that Nox-targeted therapy may be effective for treatment with RA.

\section{REFERENCES :}

[1] Drummond GR, Selemidis S, Griendling KK, Sobey CG. Combating oxidative stress in vascular disease: NADPH oxidases as therapeutic targets. Nat Rev Drug Discov 2011;10:453-71.

[2] Neumann E, Lefèvre S, Zimmermann B, Gay S, Müller-Ladner U. Rheu matoid arthritis progression mediated by activated synovial fibroblasts. Trends Mol Med 2010;16:458-68.

[3] Rodiño-Janeiro BK, Paradela-Dobarro B, Castiñeiras-Landeira MI, Raposeiras-Roubín S, González-Juanatey JR, Alvarez E. Current status of NADPH oxidase research in cardiovascular pharmacology. Vasc Health Risk Manag 2013;9:401-28.

[4] Xiao C, Li J, Dong X, He X, Niu X, Liu C, Zhong G, Bauer R, Yang D, Lu A. Anti-oxidative and TNF- $\alpha$ suppressive activities of puerarin derivative (4AC) in RAW264.7 cells and collagen-induced arthritic rats. Eur J Pharmacol 2011;666:242-50.

[5] Yun JM, Chien A, Jialal I, Devaraj S. Resveratrol up-regulates SIRT1 and inhibits cellular oxidative stress in the diabetic milieu: mechanistic insights. J Nutr Biochem 2012;23:699-705.

Disclosure of Interest: None declared

DOI: 10.1136/annrheumdis-2018-eular.6702 